\title{
Prevalence of arterial hypertension and associated factors: a population-based study
}

\author{
(iD) Layanne Cristina de Carvalho Lavôr ${ }^{1}$ \\ (iD) Rosana Rodrigues de Sousa ${ }^{1}$ \\ (i) Lays Arnaud Rosal Lopes Rodrigues ${ }^{1}$ \\ (iD) Onias de Sousa Rodrigues Filho ${ }^{2}$ \\ (iD) Adriana de Azevedo Paiva ${ }^{1}$ \\ Karoline de Macêdo Gonçalves Frota ${ }^{1}$
}

1. Departamento de Nutrição, Centro de Ciências da Saúde, Universidade Federal do Piauí, Teresina, PI, Brasil. 2. Hospital Universitário da Universidade Federal do Piauí, Teresina, PI, Brasil.

\section{SUMMARY}

OBJECTIVE: To estimate the prevalence of hypertension in adults and analyze its association with socioeconomic, demographic, and lifestyle risk factors.

METHODS: Home-based cross-sectional epidemiological study conducted with adults of both sexes living in the cities of Teresina and Picos (PI). The prevalence of hypertension was estimated by self-reported diagnosis. The associations between hypertension and the following variables were tested: age, gender, skin color, education, family income, marital status, alcohol and cigarette consumption, physical activity, and nutritional status.

RESULTS: A total of 1,057 adult individuals with a mean age of $38.6 \pm 11.5$ years participated in the study, of which $62.3 \%$ were female. The prevalence of hypertension in the population was $16.4 \%$. In the crude analysis, a significant association was observed between the prevalence of hypertension and factors such as older age, lower education, single marital status, brown skin color, smoking, and overweight ( $p$ 0.05). However, after adjustments, only the associations with older age, brown skin color, sedentary lifestyle and overweight remained significant.

CONCLUSION: Older age, brown skin color, sedentary lifestyle, and the presence of overweight or obesity were significantly associated with hypertension. Among the modifiable risk factors, a sedentary lifestyle and overweight stand out as important for the genesis of hypertension, subject to intervention measures.

KEYWORDS: Hypertension. Adult health. Health surveys. Risk factors.

\section{INTRODUCTION}

Elevations in arterial pressure have been recognized as a health problem due to their impact on the mortality of the world population. Systemic arterial hypertension ( $\mathrm{SAH})$ is an important risk factor for cardiovascular diseases, and is responsible for $62 \%$ of cerebral vascular accidents and $49 \%$ of coronary artery diseases and renal diseases, with a significant contribution to the global burden of disease and years of life lost due to disability. Such consequences entail increased costs of health systems and relevant socioeconomic impact ${ }^{1.2}$.

$\mathrm{SAH}$ is a challenge for public health with 
approximately 600 million hypertensive individuals worldwide and a tendency of a significant increase in its prevalence, with estimates of a global growth of $60 \%$ of the cases by 2025 . In Brasil, it affects $32.5 \%$ (36 million) of adult individuals. In Teresina, in the Piauí state, the prevalence of self-reported hypertension is $20.8 \%^{3-5}$.

Factors such as age, sex, education, smoking, alcoholism, and marital status have been associated with changes in blood pressure. Other factors such as population aging and behavioral factors, such as changes in dietary patterns and physical inactivity, have been attributed to the progressive increase of overweight and obesity, which are directly related to an increase in the prevalence of $\mathrm{SAH}^{6.7}$.

Population health surveys have been increasingly used and are essential for establishing the health profile, distribution of risk factors and their trends, in addition to providing information about self-referred morbidity and lifestyle. Repeated with a certain periodicity, the surveys allow to consolidate information collected as a reference population database to surveil several chronic diseases and their determining factors ${ }^{8}$.

Even with the advances in health, there are still controversial issues on SAH, especially regarding etiological and pathophysiological aspects that suggest appropriate forms of prophylaxis and early identification of the population at risk for hypertension?.

Due to the high prevalence of SAH in the Brazilian population and the magnitude of the impact of its consequences in health and, consequently, in the productive capacity of the economically active population, which leads also to a greater financial impact in families, society, and the government, it is important to know the determining factors of this pathology to provide data that subsidize actions and policies of prevention and control.

Therefore, the objective of this study was to estimate the prevalence of arterial hypertension in adults of two municipalities of Piauí and analyze its association with socioeconomic, demographic, and lifestyle risk factors.

\section{METHODS}

This is a cross-sectional epidemiological study, household-based, with data from the Population-Based Health Survey in the Municipalities of Teresina and Picos - PI (ISAD-PI). For this study, we used a sample of
1057 adult individuals aged between 20 and 59 years.

The sample size was calculated based on complex probability sampling, by conglomerates, in two stages: the census sector and household. To improve the efficiency of sampling, the census sectors of the urban area were, when necessary, fanned or grouped according to pre-established criteria to obtain the primary sampling units (PSUs), which were then ordered, with probability proportional to size, so that all socioeconomic groups were represented.

In the second stage, thirty (30) sectors were systematically selected with probability proportional to size within each PSU and, finally, a systematic sampling of 25 to 30 households was randomly selected in each sector, in the cities of Teresina and Picos (PI), with an expectation of $20 \%$ of loss and $5 \%$ of closed households. All those residing in the households selected were invited to participate in the research.

The demographic, socioeconomic, lifestyle, and health profile data were obtained through structured questionnaires, adapted from surveys used previously in other Brazilian epidemiological studies ${ }^{8.10}$. The questionnaires were administered by trained researchers, using the Epicollect $5^{\circledR}$ application (Imperial College London) on mobile devices (https://five.epicollect.net/ project/isad).

We collected data on demographic (age, gender, self-reported skin color, marital status, education), socioeconomic (family income), lifestyle (physical activity, smoking, and alcoholism), and self-reported medical diagnosis of hypertension. After the survey, we conducted an anthropometric assessment. In the case of closed households (absence), the interviewer returned up to three times before considering sample loss.

The anthropometric measurement was performed twice in each individual. The data of height and weight were measured according to the recommendations of Cameron ${ }^{11}$ and Jelliffe $\&$ Jelliffe ${ }^{12}$. The weight was measured in kilograms $(\mathrm{kg})$ using the SECA ${ }^{\circledR}$ digital scale, with a maximum capacity of $150 \mathrm{~kg}$ and an accuracy of $0.1 \mathrm{Kg}$. Height was measured in meters using a portable stadiometer, with an accuracy of $0.1 \mathrm{~cm}$.

The classification of nutritional status was performed from the calculation of Body Mass Index (BMI), by dividing the weight in kilograms by the height in square meters ${ }^{13}$. The subsequent classification into underweight/eutrophic, overweight, and obesity was done according to the classification proposed by the WHO (2000).

All statistical analyzes were performed using the 


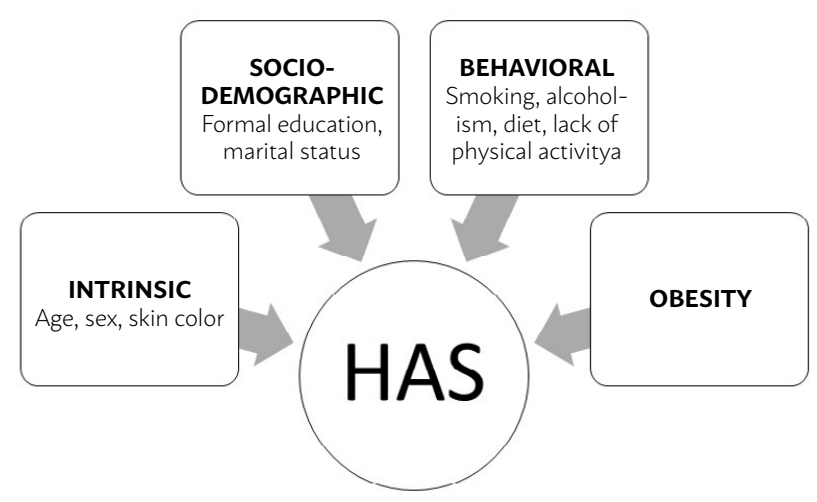

FIGURE 1. FACTORS ASSOCIATED WITH THE DEVELOPMENT OF SYSTEMIC ARTERIAL HYPERTENSION. LAVOR ET AL., 2019.

Stata version 13.0 software (Stata Corporation, College Station, TX, United States 13.0). The categorical variables were presented as absolute and relative frequencies. Pearson's chi-square test was applied to verify the association between the categorical variables. The association between hypertension and associated factors was by Poisson regression with robust variance, expressed as Prevalence Ratios (PR) and confidence intervals of $95 \%$ (95). The results were expressed in crude analysis and adjusted for potential confounding factors. |Variables with $\mathrm{p}<0.20$ in the crude analysis were kept in the model. For all statistical tests, p-values $<0.05$ were established as statistically significant.

The research was approved by the Research Ethics Committee of the Federal University of Piauí (CEP/ UFPI), decision No. 2.552 .426, pursuant to the legislation of ethics in research involving human beings, Resolution $466 / 12^{14}$.

\section{RESULTS}

Of the 1,057 adults in the study, $658(62.3 \%)$ were female. The average age of the population was 38.6 \pm 11.5 years; $37.6 \pm 11.6$ for males and $39.3 \pm 11.5$ for females. As for the sociodemographic characteristics, most of the population were aged between 40 and 59 years, had studied up Upper Secondary Education, had a family income lower than two minimum wages per month, brown skin color, and were married or in a stable union (Table 1). With respect to lifestyle, most of the population did not smoke nor consumed alcohol in an abusive manner. However, $77.2 \%$ of the participants were sedentary, and $59.7 \%$ had excess weight.

The overall prevalence of SAH in the adult population was $16.4 \%(n=166)$, and it was significantly
TABLE 1. DESCRIPTIVE CHARACTERISTICS OF THE STUDY POPULATION.

\begin{tabular}{|c|c|c|}
\hline Variables & $n(\%)$ & $\begin{array}{l}\text { Prevalence of hy- } \\
\text { pertension } \mathrm{n}(\%)\end{array}$ \\
\hline \multicolumn{3}{|l|}{ Age } \\
\hline $20-29$ & $276(26.1)$ & $11(4.15)$ \\
\hline 30-39 & $284(26.9)$ & $28(10.4)$ \\
\hline $40-59$ & $497(47.0)$ & $127(26.7)$ \\
\hline \multicolumn{3}{|l|}{ Sex } \\
\hline Male & $399(37.7)$ & $59(15.5)^{\star}$ \\
\hline Female & $658(62.3)$ & $107(17.0)^{\star}$ \\
\hline \multicolumn{3}{|l|}{ Formal education } \\
\hline Illiterate & $30(2.8)$ & $11(6.5)$ \\
\hline Elementary Education & $303(28.7)$ & $69(41.0)$ \\
\hline Secondary Education & $393(37.2)$ & $48(28.6)$ \\
\hline Higher Education & $331(31.3)$ & $40(23.8)$ \\
\hline \multicolumn{3}{|l|}{ Family income } \\
\hline$\leq 2$ minimum wages & $599(63.4)$ & $107(18.2)$ \\
\hline$>2$ minimum wages & $346(36.6)$ & 48 (14.3) \\
\hline \multicolumn{3}{|l|}{ Skin color } \\
\hline White & 185 (17.9) & $38(22.9)$ \\
\hline Black & $147(14.3)$ & $30(18.1)$ \\
\hline Brown & $623(60.5)$ & $90(54.2)$ \\
\hline Others & $75(7.3)$ & $8(4.8)$ \\
\hline \multicolumn{3}{|l|}{ Marital status } \\
\hline Married & $614(59.6)$ & $112(18.5)$ \\
\hline Single & $330(32.0)$ & $37(11.4)$ \\
\hline Widowed/divorced & $86(8.4)$ & $17(21.0)$ \\
\hline \multicolumn{3}{|l|}{ Smoker } \\
\hline Yes & $226(22.0)$ & $109(13.9)$ \\
\hline No & $800(78.0)$ & $57(25.4)$ \\
\hline \multicolumn{3}{|l|}{ Alcohol consumption } \\
\hline Yes & $158(15.4)$ & $25(16.3)$ \\
\hline No & $869(84.6)$ & $140(16.4)$ \\
\hline \multicolumn{3}{|l|}{ Physical activity ( $n=960)$} \\
\hline Active & $219(22.8)$ & $29(13.9)$ \\
\hline Sedentary & 741 (77.2) & $122(17.2)$ \\
\hline \multicolumn{3}{|l|}{ Nutritional status } \\
\hline Eutrophy & $424(40.3)$ & $35(8.62)$ \\
\hline Overweight & $392(37.2)$ & $62(16.5)$ \\
\hline Obesity & $237(22.5)$ & $69(30.4)$ \\
\hline
\end{tabular}

associated with increased age, less schooling, single marital status, brown skin color, smoking, and excess weight. The population aged 40 to 59 years presented a prevalence ratio 6.44 times greater in relation to younger adults aged 20 to 29 years. Regarding the nutritional status, obese individuals presented a prevalence ratio for hypertension 3.52 times greater when compared to eutrophic individuals (Table 2).

However, after adjustments for the variables of age and skin color, only the SAH prevalence reasons of increased age, brown skin color, and excess 
TABLE 2. PREVALENCE AND PREVALENCE RATIO OF ARTERIAL HYPERTENSION ACCORDING TO SOCIODEMOGRAPHIC, LIFESTYLE, AND NUTRITIONAL STATUS VARIABLES

\begin{tabular}{|c|c|c|c|c|}
\hline \multirow{2}{*}{ Variables } & \multicolumn{4}{|c|}{ Prevalence ratio (PR) } \\
\hline & Crude $(\mathrm{Cl})$ & $p$ & Adjusted $(\mathrm{Cl})^{*}$ & $p$ \\
\hline \multicolumn{5}{|l|}{ Age } \\
\hline $20-29$ & 1.0 & & 1.0 & \\
\hline $30-39$ & $2.49(1.2-4.9)$ & 0.008 & $2.58(1.3-5.2)$ & 0.008 \\
\hline $40-59$ & $6.44(3.5-11.7)$ & 0.001 & $6.67(3.6-12.3)$ & 0.001 \\
\hline \multicolumn{5}{|l|}{ Gender } \\
\hline Male & 1.0 & & 1.0 & \\
\hline Female & $1.10(0.79-1.50)$ & 0.562 & $1.02(0.74-1.40)$ & 0.887 \\
\hline \multicolumn{5}{|l|}{ Formal education } \\
\hline Illiterate & $3.14(1.60-6.13)$ & 0.001 & $1.67(0.85-3.30)$ & 0.136 \\
\hline Elementary Education & 1.89 (1.27-2.79) & 0.001 & $1.21(0.81-1.81)$ & 0.350 \\
\hline Secondary Education & $0.98(0.63-1.49)$ & 0.921 & $0.86(0.56-1.31)$ & 0.496 \\
\hline Higher Education & 1.0 & & 1.0 & \\
\hline \multicolumn{5}{|l|}{ Family income } \\
\hline$>2$ minimum wages & 1.0 & & 1.0 & \\
\hline$\leq 2$ minimum wages & $1.27(0.90-1.78)$ & 0.166 & $1.24(0.88-1.74)$ & 0.210 \\
\hline \multicolumn{5}{|l|}{ Skin color } \\
\hline White & 1.0 & & 1.0 & \\
\hline Black & $0.98(0.60-1.58)$ & 0.934 & $1.03(0.64-1.66)$ & 0.895 \\
\hline Brown & $0.69(0.47-1.01)$ & 0.063 & $0.66(0.45-0.96)$ & 0.033 \\
\hline Others & $0.51(0.24-1.09)$ & 0.085 & $0.47(0.22-1.02)$ & 0.058 \\
\hline \multicolumn{5}{|l|}{ Marital status } \\
\hline Married & 1.0 & & 1.0 & \\
\hline Single & $0.61(0.43-0.87)$ & 0.011 & $1.06(0.72-1.57)$ & 0.734 \\
\hline Widowed/divorced & $1.13(0.71-1.78)$ & 0.634 & $0.93(0.56-1.56)$ & 0.803 \\
\hline \multicolumn{5}{|l|}{ Smoking } \\
\hline No & 1.0 & & 1.0 & \\
\hline Yes & $1.82(1.32-2.31)$ & 0.001 & $1.37(0.1-1.9)$ & 0.057 \\
\hline \multicolumn{5}{|l|}{ Alcohol consumption } \\
\hline No & 1.0 & 0.979 & 1.0 & 0.843 \\
\hline Yes & 0.99 (0.64-1.52) & & $1.04(0.7-1.6)$ & \\
\hline \multicolumn{5}{|l|}{ Physical activity } \\
\hline Active & 1.0 & & 1.0 & \\
\hline Sedentary & $1.23(0.82-1.85)$ & 0.301 & $1.53(1.01-2.30)$ & 0.040 \\
\hline \multicolumn{5}{|l|}{ Nutritional status } \\
\hline Eutrophy & 1.0 & & 1.0 & \\
\hline Overweight & $1.91(1.26-2.90)$ & 0.002 & $1.56(1.03-2.37)$ & 0.035 \\
\hline Obesity & $3.52(2.34-5.29)$ & 0.001 & $2.64(1.75-3.98)$ & 0.001 \\
\hline
\end{tabular}

*Adjusted for age and skin color.

weight remained significant. In addition, after these adjustments, sedentary individuals showed a ratio of prevalence 1.53 times higher for hypertension when compared to active individuals.

\section{DISCUSSION}

The prevalence of hypertension found in this study was $16.4 \%$ for adult individuals aged from 20 to 59 years, residents of the cities of Teresina and Picos (PI). This value was similar to that found in a study conducted on adults living in Campinas, whose prevalence of hypertension was $14.0^{15}$. On the other hand, the prevalence of the disease found in this study was lower than that found in a study performed with adults of the sertão region of Pernambuco, which was $27.4 \%{ }^{16}$. This divergence between the studies may be due to differences in how the diagnosis of hypertension was obtained since, in the present study, it was self-reported form, whereas in the study mentioned it was measured. 
The prevalence of hypertension was significantly associated with increased age, and this association remained significant even after adjustments for skin color. Similar results were observed in other Brazilian population studies ${ }^{15,17-19}$. The higher prevalence of hypertension in the population with advanced age may be explained by the natural hardening of arteries and aortas that occurs with the increase of age $\mathrm{e}^{20}$. Over time, the walls of the great arteries, especially the aorta, thicken and lose elasticity, and this process results in an increased pulse wave velocity, a reliable measure of arterial stiffness. This increase of stiffness would reduce the dampening function of the arteries near the heart as well as increase the pulse wave velocity, causing higher systolic and pulse pressure ${ }^{21}$.

As to the level of schooling, we found that the less formal education, the greater the prevalence ratio for arterial hypertension. This fact has been corroborated by other studies ${ }^{15.17}$. However, after adjustments for confounding variables, schooling was not significantly associated with hypertension.

As to skin color, we observed a significant association between individuals that self-reported as brown-skinned and the prevalence of hypertension, regardless of age, and we observed a lower ratio of prevalence of the disease in these individuals when compared to blacks and whites. This goes against the findings of a systematic review in which most of the studies investigated found that individuals of nonwhite skin color had a higher prevalence of $\mathrm{SAH}^{22}$.

Regarding marital status, single individuals were significantly associated with the prevalence of hypertension, indicating protection against the outcome, since unmarried individuals showed less prevalence of hypertension when compared to those married, widowed, or divorced. This result corroborates that found by Zangirolani et al. ${ }^{15}$, who observed a higher prevalence of the disease in individuals separated or widowed when compared to singles. However, in the present study, in the adjusted analysis, this association was not statistically significant.

In the crude analysis of the prevalence ratio, smoking was significantly associated with hypertension in our population, corroborating other studies performed with Brazilian adults ${ }^{15,16,23}$. Smoking causes higher blood pressure, increasing up to two times the risk of hypertension and causing a greater variability in blood pressure levels, which can lead to injuries in target organs ${ }^{24}$. However, in the present study, after adjustments for confounding variables, the association between smoking and hypertension was not significant.

Regarding physical activity, we observed that after the Poisson regression analysis adjusted for age and skin color, individuals with a sedentary lifestyle had a prevalence ratio significantly 1.53 times greater for hypertension when compared to active individuals. This corroborates the already well-established role of physical inactivity as an important risk factor for chronic non-communicable diseases, which are responsible for more than three million deaths yearly ${ }^{15}$. Several mechanisms explain the relationship between the regular practice of physical activity and the reduction of blood pressure levels, such as the improvement of oxidative stress, inflammation, endothelial function, body mass index, as well as the activity of the renin-angiotensin system, the parasympathetic system, renal function, and insulin sensitivity ${ }^{25}$.

In the present study, the presence of excess weight and obesity presented as an important factor associated with the presence of hypertension in the adult population, increasing significantly the prevalence ratio for hypertension, the higher the condition of excess weight. In a systematic review, obesity appeared as the main anthropometric factor associated with the prevalence of $\mathrm{SAH}^{24}$. This was also observed in other Brazilian studies ${ }^{15-19}$. It is estimated that between 20 to $30 \%$ of the prevalence of this pathology can be explained by the association between excess weight and its increased risk ${ }^{19}$.

This study has limitations, such as the self-reported diagnosis of hypertension, which can result in the underdiagnosis of the disease since many individuals may be hypertensive but not aware of it. In addition, the cross-sectional nature of the study does not allow to establish relations of causality between the exposure to the factors and the development of the disease. The strength of this study is the representativeness of the sample, which includes the capital and a city in the interior of Minas Gerais.

\section{CONCLUSION}

In this study, factors such as age, brown skin color, sedentary lifestyle, and overweight or obesity were significantly associated with the presence of hypertension. Among the modifiable risk factors, we highlight sedentary lifestyles and excess weight as important for the genesis of hypertension and modifiable based on intervention measures. In this sense, 
it is important to emphasize the role of public policies to prevent and control excess weight in the population by encouraging the practice of regular physical activity and aiming not only to reduce the risk of hypertension as well as other chronic non-communicable diseases.

\section{Contribution of the authors}

Layanne Cristina de Carvalho Lavôr: the original draft (leadership). Data collection (egalitarian) Conceptualization (egalitarian), formal analysis (leadership), methodology (leadership), project management (egalitarian), supervision (egalitarian), visualization (leadership). Rosana Rodrigues de Sousa, Lays Arnaud Rosal Lopes Rodrigues and Onias de Sousa Rodrigues Filho: Data collection (egalitarian) Conceptualization (egalitarian), formal analysis (leadership), methodology (leadership), project management (egalitarian), supervision (egalitarian), visualization (leadership). Adriana de Azevedo Paiva and Karoline de Macêdo Gonçalves Frota: Conceptualization (egalitarian), formal analysis (leadership), methodology (leadership), project management (leadership), supervision (leadership), visualization (leadership).

\section{RESUMO}

OBJETIVO: Estimar a prevalência de hipertensão arterial em adultos e analisar sua associação com fatores de risco socioeconômicos, demográficos e de estilo de vida.

MÉTODOs: Estudo epidemiológico transversal, de base domiciliar, realizado com adultos de ambos os sexos residentes nas cidades de Teresina e Picos (PI). A prevalência de hipertensão arterial foi estimada por meio de diagnóstico autorreferido. Foram testadas as associações entre a hipertensão arterial e as variáveis: idade, sexo, cor da pele, escolaridade, renda familiar, situação conjugal, consumo de álcool e cigarro, prática de atividade física e estado nutricional.

RESULTADOS: Participaram do estudo 1.057 indivíduos adultos com média de idade de 38,6 \pm 11,5 anos, sendo 62,3\% do sexo feminino. A prevalência de hipertensão arterial na população foi de 16,4\%. Na análise bruta, observou-se associação significativa entre a prevalência de hipertensão e fatores como maior idade, menor escolaridade, estado civil solteiro, cor da pele parda, tabagismo e excesso de peso $(p<0,05)$. Entretanto, após ajustes, apenas as associações com a maior idade, cor da pele parda, estilo de vida sedentário e excesso de peso mantiveram-se significativas.

CONCLUSÃO: A idade mais avançada, cor da pele parda, sedentarismo e a presença de sobrepeso ou obesidade apresentaram-se significativamente associados à hipertensão. Dentre os fatores de risco modificáveis, destaca-se o sedentarismo e o excesso de peso como importantes para a gênese de hipertensão e passíveis de medidas de intervenção.

PALAVRAS-CHAVE: Hipertensão. Saúde do adulto. Inquéritos epidemiológicos. Fatores de risco.

\section{REFERENCES}

1. Lackland DT, Weber MA. Global burden of cardiovascular disease and stroke: hypertension at the core. Can J Cardiol. 2015;31(5):569-71.

2. Rimárová K, Dorko E, Diabelková |, Sulinová Z, Frank K, Baková J, et al. Anthropometric predictors of systolic and diastolic blood pressure considering intersexual differences in a group of selected schoolchildren. Cent Eur | Public Health. 2018;26(Suppl):S4-S11.

3. World Health Organization. Global status report on noncommunicable diseases 2014. Geneva: World Health Organization; 2014. 298p.

4. Malachias MVB, Souza WKSB, Plavnik FL, Rodrigues CIS, Brandão AA, Neves MFT, et al. 7a Diretriz brasileira de hipertensão arterial. Arq Bras Cardiol. 2016;107(3 Supl. 3):1-83.

5. Brasil. Ministério da Saúde, Agência Nacional de Saúde Suplementar. Vigitel Brasil 2015. Saúde suplementar: vigilância de fatores de risco e proteção para doenças crônicas por inquérito telefônico. Brasília: Ministério da Saúde; 2017. $170 p$.

6. Sebati RB, Monyeki KD, Monyeki MS, Motloutsi B, Toriola AL, Monyeki MJ. Ellisras longitudinal study 2017: the relationship between waist circumference, waist-to-hip ratio, skinfolds and blood pressure among young adults in Ellisras, South Africa (ELS 14). Cardiovasc J Afr. 2018;30(1):24-8.

7. Luz RH, Barbosa AR, d'Orsi E. Waist circumference, body mass index and waist-height ratio: Are two indices better than one for identifying hypertension risk in older adults? Prev Med. 2016;93:76-81.
8. Szwarcwald CL, Malta DC, Pereira CA, Vieira MLFP, Conde WL, Souza Junior PRB, et al. Pesquisa Nacional de Saúde no Brasil: concepção e metodologia de aplicação. Ciênc Saúde Coletiva. 2014;19(2):333-42.

9. Barreto Neto AC, Araújo EC, Silva KVP, Pontes LM. Prevalência de hipertensão e fatores associados em adolescentes escolares no sertão de Pernambuco. Adolesc Saúde. 2010;7(4):22-9.

10. Fisberg RM, Marchioni DML. Manual de avaliação do consumo alimentar em estudos populacionais: a experiência do inquérito de saúde em São Paulo (ISA). São Paulo: Faculdade de Saúde Pública da Universidade de São Paulo, 2012. 197p.

11. Cameron N. Anthropometric measurements. In: The measurement of human growth. London: Croom Helm; 1984. p.56-99.

12. Jelliffe DB, Jelliffe EFP. Anthropometry: major measurements. In: Jelliffe DB, Patrice Jelliffe, EF, eds. Community nutritional assessment. Oxford: Oxford University Press; 1989. p.68-105.

13. World Health Organization. Report of a WHO Consultation (WHO Technical Report Series 894). Geneva: World Health Organization; 2000.

14. Brasil. Ministério da Saúde. Resolução n. 466/12. Conselho Nacional de Pesquisa com Seres Humanos. Diário Oficial da União. Brasília: Ministério da Saúde; 2012.

15. Zangirolani LTO, Assumpção D, Medeiros MAT, Barros MBA. Hipertensão arterial autorreferida em adultos residentes em Campinas, São Paulo, Brasil: 
prevalência, fatores associados e práticas de controle em estudo de base populacional. Ciênc Saúde Coletiva. 2018;23(4):1221-32.

16. Santiago ERC, Diniz AS, Oliveira JS, Leal VS, Andrade MIS, Lira PIC. Prevalência e fatores associados à hipertensão arterial sistêmica em adultos do sertão de Pernambuco, Brasil. Arq Bras Cardiol. 2019;113(4):687-95.

17. Silva EC, Martins MSAS, Guimarães LV, Segri NJ, Lopes MAL, Espinosa MM. Prevalência de hipertensão arterial sistêmica e fatores associados em homens e mulheres residentes em municípios da Amazônia Legal. Rev Bras Epidemiol. 2016;19(1):38-51.

18. Andrade SSCA, Malta DC, Iser BM, Sampaio PC, Moura L. Prevalência da hipertensão arterial autorreferida nas capitais brasileiras em 2011 e análise de sua tendência no período de 2006 a 2011. Rev Bras Epidemiol. 2014;(suppl PeNSE):215-26.

19. Muraro AP, Santos DF, Rodrigues PRM, Braga JU. Fatores associados à hipertensão arterial sistêmica autorreferida segundo VIGITEL nas 26 capitais brasileiras e no Distrito Federal em 2008. Ciênc Saúde Coletiva. 2013;18(5):1387-98.
20. Singh S, Shankar R, Singh GP. Prevalence and associated risk factors of hypertension: a cross-sectional study in urban Varanasi. Int J Hypertens. 2017;2017; 5491838

21. Sun Z. Aging, arterial stiffness and hypertension. Hypertension. 2015;65(2):252-6

22. Galvão RRS, Soares DA. Prevalência de hipertensão arterial e fatores associados em adultos: uma revisão na literatura brasileira. Rev APS. 2016;19(1):139-49.

23. Malta DC, Bernal RTI, Andrade SSCA, Silva MMA, Velasquez-Melendez G. Prevalência e fatores associados com hipertensão arterial autorreferida em adultos brasileiros. Rev Saúde Pública. 2017;51(supl. 1):11s.

24. Marques AP, Szwarcwald CL, Pires DC, Rodrigues IM, Almeida WS, Romero D. Fatores associados à hipertensão arterial: uma revisão sistemática. Cien Saude Colet [periódico na internet] (2018/Out). [cited 2019 Oct 3]. Available from: http://www.cienciaesaudecoletiva.com.br/artigos/fatores-associados-a-hipertensao-arterial-uma-revisao-sistematica/16981?id=16981

25. Hegde SM, Solomon SD. Influence of physical activity on hypertension and cardiac structure and function. Curr Hypertens Rep. 2015;17(10):77. 